UDC 613.6-616-057: 616-006.1

DOI: 10.21668/health.risk/2017.1.11.eng

\title{
ASSESSING OCCUPATIONAL CARCINOGENIC RISKS FOR HEALTH OF WORKERS EMPLOYED AT BLISTER COPPER PRODUCTION ENTERPRISE
}

\author{
V.I. Adrianovskiy ${ }^{1,2}$, G.Ya. Lipatov ${ }^{1,2}$, E.A. Kuz'mina ${ }^{1}$, N.V. Zlygosteva ${ }^{1,2}$, \\ K.Yu. Russkikh ${ }^{1}$, N.P. Sharipova ${ }^{2}$, T.V. Bushueva' ${ }^{1}$, V.O. Ruzakov ${ }^{3}$ \\ ${ }^{1}$ Yekaterinburg Medical Scientific Center for Prevention and Health Protection for workers employed \\ at industrial enterprises, 30 Popova Str., Yekaterinburg, 620014, Russian Federation \\ ${ }^{2}$ Ural State Medical University, 3 Repina Str., Yekaterinburg, 62002, Russia Federation \\ ${ }^{3}$ Administration of the Federal Supervision Service for Consumer's Rishts Profection and Human Welfare \\ in the Sverdlovsk Region, 3 Otdelnyi pereulok, 620078, Russian Federation
}

In order to develop ideological grounds for complex assessment of industrial carcinogenic danger, we performed hygienic assessment of contribution made by working environment factors into carcinogenic risks formation for workers employed at blister copper production. The assessment included predictive values of occupational risks. We determined tumor markers levels for occupations with unacceptable levels of carcinogenic risks. We examined mortality caused by malignant neoplasms. It is shown that non-organic arsenic compounds applied in blister copper production are the main factor causing carcinogenic risks. As we calculated individual carcinogenic risks for 25-year working period we found out that total carcinogenic risks for all basic and supplementary occupations in copper-smelting workshops were within the 4th range (more than $1.0 \times 10^{-3}$ ). Unacceptable predictive values of carcinogenic risks for $100 \%$ examined occupations appeared already after 5 years of work. We detected excess levels of tumor markers in $73 \%$ of examined workers with occupations characterized with unacceptable values of carcinogenic risks; $19 \%$ of such workers had excess levels of two tumor markers at once. $9 \%$ of examined workers had excess levels of Cyfra 21.1 tumor marker, 14,5\% of workers had high levels of CEA tumor marker, and $59 \%$ of workers had high levels of NSE tumor marker. Intensive mortality indices for male workers employed at copper-smelting workshops as per all localizations amounted to 153.14, whereas they amounted to only 127.25 per 100,000 people for other population groups. Workers employed at blister copper production had higher intensive mortality indices than other people in terms of such nosologies as malignant neoplasms in respiratory organs and chest (86.78 and 47.72 correspondingly), including lung cancer (71.47 and 43.48 correspondingly. The obtained results will help to work out a system for managing carcinogenic risks which will include regulating and controlling activities, managerial activities, technical and technological measures, financial and economic activities, medical and prevention activities plus rehabilitation activities, as well as information and educational activities.

Key words: blister copper production, occupational individual carcinogenic risk, mortality caused by malignant neoplasms, tumor markers, carcinogenic risk management, arsenic, nickel, lead, cadmium.

(C) Adrianovskiy V.I., Lipatov G.Ya., Kuz’mina E.A., Zlygosteva N.V., Russkikh K.Yu., Sharipova N.P., Bushueva T.V., Ruzakov V.O., 2017

Vadim I. Adrianovskiy - Candidate of Medical Sciences, associate professor; senior researcher at cancer prevention epidemiology laboratory (e-mail: adrianovsky@k66.ru; tel.: +7 (343) 253-14-56).

Georgiy Ya. Lipatov - Doctor of Medical Sciences, Professor; head of cancer prevention epidemiology laboratory (e-mail: lipatovg@ymrc.ru; tel.: +7 (343) 253-14-56).

Elena A. Kuz'mina - Candidate of Medical Sciences, head of complex hygienic problems and population morbidity prevention department (e-mail: risk@ymrc.ru; tel.: +7 (343) 371-81-29).

Natalia V. Zlyigosteva - junior researcher at cancer prevention epidemiology laboratory (e-mail: kirakirazn@gmail.com; tel.: +7 (343) 253-14-56).

Kseniya Yu. Russkikh - junior researcher at cancer prevention epidemiology laboratory (e-mail: russkihk300185@mail.ru; tel.: +7(343) 253-14-56).

Natalia P. Sharipova - Candidate of Medical Sciences, assistant at hygiene and occupational diseases department (e-mail: isaeva20a@yandex.ru; tel.: +7 (343) 214-86-93).

Tatyana V. Bushueva - Candidate of Medical Sciences, leading researcher at "Diagnostics Research Techniques" Scientific Production Association (e-mail: gribova@ymrc.ru; tel.: +7 (343) 371-27-48).

Vadim O. Ruzakov - head of Labour hygiene control department (e-mail: mail@66.rospotrebnadzor.ru; tel.: +7 (343) 270-15-69). 
Nowadays practically one third of workers in Russia have to work in hazardous and dangerous working environment. As per International Labor Organization assessment, more than 76,000 death cases in Russia are caused by occupational diseases. This situation calls for changes in priorities when planning strategies aimed at population health improvement; namely. the focus needs to be shifted from clinical approach to prevention programs implementation. Therefore, managing occupational risks becomes a most vital task and it means working out a set of activities for preventing adverse impacts exerted by working conditions on health; these activities are to be based on assigning top priority to primary prevention and lowering risk factors influence [16].

P.V. Serebryakov (2007), A.V. Meltser (2008), and some other authors dedicated their research to development of carcinogenic risk assessment methodology. In particular, P.V. Serebryakov was the first to work out an algorithm for calculating individual occupational carcinogenic risks; this algorithm was tested at enterprises which specialized in extracting and processing copper-nickel ores [14]. Issues of occupational exposure to carcinogens, risk assessments and biological monitoring (on the example of arsenic compounds) are also profoundly discussed in foreign scientific literature $[17,18,20]$.

Since 2011 Rospotrebnadzor offices and establishments in Sverdlovsk region, together with FBSE "Yekaterinburg medical scientific center for prevention and protection of workers employed at industrial enterprises", have been developing ideological grounds for complex assessment of enterprises' carcinogenic danger [9]. As per results of assessing exposure to carcinogenic factors and working population characteristics, predictive values of individual occupational carcinogenic risk (CR) are calculated; these values are then compared with risks related to non-production impacts. These CR assessments enable researchers to form a risk group of workers who then undergo additional research on early detection of neoplasms signs during preventive examinations; when it is necessary, such workers have additional examinations in a hospital with further regular medical checkups. In order to give grounds for production factors contribution into malignant neoplasms (MN) evolvement, research on workers' oncologic mortality is conducted. All the above-stated allows us to justify activities aimed at managing carcinogenic risks.

However, there is a number of methodological problems related to calculation of predictive CR values as its aspects, values and criteria are not confirmed in accordance with the established procedure; there is also an issue of assessing proof of relation between an occupation and cancer evolvement as well as determining tumor formation predictors $[7,15]$.

Our research goal was to examine working conditions and assess occupational carcinogenic risks for workers employed at enterprises dealing with blister copper production.

Data and methods. We chose a major enterprise in the Urals specializing in blister copper production as our research object; production in copper-smelting workshop at this enterprise combined such technological processes as mix materials drying, smelting in Vanyukov's furnace (PV-1500), and copper converting.

At the first stage of our research we identified the enterprise carcinogenic danger basing on the initial data taken from its sanitary-hygienic certificate. We determined priority carcinogenic factors of production components (raw materials, products, emissions into atmosphere, sewage discharge, air composition in working area etc.) and formed a data bank (on concentrations) for further assessment of occupational carcinogenic health risk. We based our CR calculations on approaches stated in $P$ 2.1.10.1920-04. "Guidelines on assessment of population health risk under exposure to chemicals which pollute environment" [8] and research conducted by A.V. Meltser and P.V. Serebryakov $[5,14]$. CR was calculated for 17 occupations of copper-smelting workshop (drying section, smelting section, and converting section); 420 people were employed at this workshop, namely: drying 
operators (6 people), carrier operators (15 people), mix materials handlers (2 people), mix materials loaders (39 people), smelters (70 people), casters (30 people), blowers (37 people), crane drivers ( 31 people), cleaners (52 people), fireproof materials handlers (3 people), foremen (12 people), powder-gas catching devices operators (44 people), pumping units operators (10 people), electrogas welders (15 people), maintenance fitters (42 people), electricians (25 people), supervisory instruments and automatic devices fitters ( 5 people), allowing for actual exposure to arsenic, cadmium, lead, beryllium, and benzpyrene ( 250 working shifts, 8 hours long each).

At the second stage, we determined tumor markers in blood serum of workers who had these occupations; tumor markers included cancer embryonic antigen (CEA) which was a marker of tumors in trachea, bronchial tubes and lungs, gastrointestinal tract, especially large intestine, pancreas, liver, as well as mammary gland, uterine neck and prostate; Cyfra 21.1 which was a marker of lung cancer (mostly epidermoid one, and less frequently adenocarcinoma and other histological types) and urinary bladder; neuron-specific enolase (NSE) which was a marker of lung tumors, leukemia and tumors of neuroectodermal origin [19].

At the third stage we performed retrospective epidemiologic research on mortality caused by malignant neoplasms among workers employed at copper-smelting workshops and having the same occupations for which CR was assessed [6]. Population living in close proximity to the enterprise was our control group. The research period was 30 years (1976-2005). We calculated intensive mortality indices per 100,000 people of population and workers (distributed as per age and total ones). In addition to the observed mortality in the examined cohorts, we calculated so called expected mortality which was control population mortality standardized as per age. We took age distribution in coppersmelting workshop as a standard. Multiplicity of excess in observed parameters of mortality caused by malignant neoplasms determined the degree of additional risk related to work at the examined production.

Results and discussion. Production aerosols are the primary occupational-hygienic hazard factor among all production factors. As ore raw materials are multi-component ones it makes determining dust chemical structure more complicated. Beside main metal, such materials contain a number of carcinogenic substances such as arsenic, nickel, cadmium, hexavalent chromium, and beryllium $[1,4,10]$. When concentrate is dried and smelted it involves benzpyrene emissions into working area air [2,3]. Dust of mix materials in smelting section contains $0.25-0.6 \%$ of arsenic, $0.05-0.09 \%$ of lead and cadmium. As for dust in converting section, it contains 0.03$0.09 \%$ of arsenic, $0.04-4.38 \%$ of lead and less than $0.1 \%$ of beryllium.

We detected increased concentrations of lead and arsenic (up to 0.1 and $0.015 \mathrm{mg} / \mathrm{m} 3$, correspondingly) for some occupations in the course of our research. Cadmium, beryllium and benzpyrene content didn't exceed maximum permissible concentration (MPC). Therefore, working conditions in coppersmelting workshop can be classified as having 2.0-3.1 hazard category.

Individual CR calculation for 25-years long working period revealed that total $\mathrm{CR}$ was within the 4th range (more than $1.0 \times 10$ 3) for all the examined main and auxiliary occupations of copper-smelting workshop (Table 1). This range is considered to be unacceptable for occupational groups [8], and it fits in with all the previous research as well as supplements them $[1,13]$.

The greatest $\mathrm{CR}$ value was detected at workplaces where dust emissions were the biggest (mix materials handler, mix materials loader, carrier operator, powder-gas catching device operator) and also for some repair occupations (electrician, maintenance fitter, supervisory instruments and automation devices fitter). The analysis of the obtained results showed that maximum contribution into CR values at all workplaces was caused by exposure to non-organic arsenic compounds (from 84 to $99 \%$ ). 
Individual carcinogenic risks for workers employed at copper-smelting workshop

\begin{tabular}{|c|c|c|c|c|c|c|}
\hline \multirow{3}{*}{ Workplace } & \multicolumn{6}{|c|}{ Carcinogenic risk at 25 -year long working period } \\
\hline & \multicolumn{5}{|c|}{ Carcinogenic substances } & \multirow{2}{*}{$\begin{array}{c}\text { Total carcinogenic } \\
\text { risk }\end{array}$} \\
\hline & As & $\mathrm{Cd}$ & $\mathrm{Pb}$ & Benzpyrene & $\mathrm{Be}$ & \\
\hline Drying operator & $3,2 \cdot 10^{-3}$ & $4,4 \cdot 10^{-5}$ & $4,6 \cdot 10^{-5}$ & - & - & $3,3 \cdot 10^{-3}$ \\
\hline Carrier operator & $4,2 \cdot 10^{-3}$ & $4,4 \cdot 10^{-5}$ & $7,5 \cdot 10^{-4}$ & - & - & $5,0 \cdot 10^{-3}$ \\
\hline Mix materials handler & $5,2 \cdot 10^{-2}$ & - & $4,4 \cdot 10^{-5}$ & - & - & $5,3 \cdot 10^{-2}$ \\
\hline Mix material loader & $7,9 \cdot 10^{-3}$ & $2,2 \cdot 10^{-5}$ & $1,2 \cdot 10^{-4}$ & - & - & $8,0 \cdot 10^{-3}$ \\
\hline Smelter & $4,2 \cdot 10^{-3}$ & $1,1 \cdot 10^{-4}$ & $9,4 \cdot 10^{-5}$ & $1,7 \cdot 10^{-6}$ & - & $4,4 \cdot 10^{-3}$ \\
\hline Caster & $3,7 \cdot 10^{-3}$ & $4,4 \cdot 10^{-5}$ & $7,8 \cdot 10^{-5}$ & - & $5,9 \cdot 10^{-5}$ & $3,9 \cdot 10^{-3}$ \\
\hline Blower & $3,7 \cdot 10^{-3}$ & $4,4 \cdot 10^{-5}$ & $7,9 \cdot 10^{-5}$ & - & $5,9 \cdot 10^{-5}$ & $3,9 \cdot 10^{-3}$ \\
\hline Crane driver & $3,2 \cdot 10^{-3}$ & $4,4 \cdot 10^{-5}$ & $7,6 \cdot 10^{-5}$ & $5,9 \cdot 10^{-5}$ & - & $3,4 \cdot 10^{-3}$ \\
\hline Cleaner & $4,2 \cdot 10^{-3}$ & $1,5 \cdot 10^{-4}$ & $9,4 \cdot 10^{-5}$ & - & - & $4,4 \cdot 10^{-3}$ \\
\hline Fireproof materials handler & $3,4 \cdot 10^{-3}$ & - & $7,6 \cdot 10^{-5}$ & $1,7 \cdot 10^{-6}$ & - & $3,5 \cdot 10^{-3}$ \\
\hline Foreman & $2,6 \cdot 10^{-3}$ & - & $5,4 \cdot 10^{-5}$ & - & - & $2,6 \cdot 10^{-3}$ \\
\hline $\begin{array}{l}\text { Powder-gas catching device } \\
\text { operator }\end{array}$ & $4,7 \cdot 10^{-3}$ & $1,5 \cdot 10^{-4}$ & $1,5 \cdot 10^{-4}$ & - & - & $5,0 \cdot 10^{-3}$ \\
\hline Pumping unit operator & $3,7 \cdot 10^{-3}$ & $4,4 \cdot 10^{-5}$ & $7,3 \cdot 10^{-5}$ & - & - & $3,8 \cdot 10^{-3}$ \\
\hline Electro-gas welder & $3,7 \cdot 10^{-3}$ & - & $6,3 \cdot 10^{-5}$ & - & - & $3,8 \cdot 10^{-3}$ \\
\hline Maintenance fitter & $5,1 \cdot 10^{-3}$ & - & $7,5 \cdot 10^{-4}$ & $1,7 \cdot 10^{-6}$ & $5,9 \cdot 10^{-5}$ & $5,9 \cdot 10^{-3}$ \\
\hline Electrician & $5,2 \cdot 10^{-2}$ & - & $7,3 \cdot 10^{-5}$ & $1,7 \cdot 10^{-6}$ & $5,9 \cdot 10^{-5}$ & $5,3 \cdot 10^{-2}$ \\
\hline $\begin{array}{l}\text { Supervisory instruments and } \\
\text { automation devices fitter }\end{array}$ & $4,7 \cdot 10^{-3}$ & - & $7,5 \cdot 10^{-5}$ & $1,7 \cdot 10^{-6}$ & $5,9 \cdot 10^{-5}$ & $4,8 \cdot 10^{-3}$ \\
\hline
\end{tabular}

Benzpyrene, beryllium, cadmium and lead content didn't exert any substantial influence on total CR values. Allowing for the obtained $\mathrm{CR}$ values, we calculated the acceptable work period length at which the upper limit of acceptable occupational risk (10-3) was reached. As a result, average acceptable working period for workers employed at copper-smelting workshop amounted to 5 years.

Research on assessment of multienvironment population carcinogenic risks which were caused by exposure to carcinogenic substances from various sources such as atmosphere, drinking water and food stuffs, showed that individual $\mathrm{CR}$ for population in a city where the examined enterprise was located amounted to $2.3 \times 10-3$ (the 4th risk range) [12]. The main contribution into multi-environment carcinogenic risk was made by arsenic, as it was in the case of occupational carcinogenic risk [11].

We determined Cyfra 21.1, CEA and NSE tumor markers in blood serum in the course of periodical medical examination (PME) of workers. Our research revealed that $73 \%$ examined workers had excess levels of tumor markers; $19 \%$ workers had excess levels of two tumor markers at once. $9 \%$ workers had increased Cyfra 21.1. tumor marker; $14.5 \%$, increased CEA tumor marker; 59\%, increased NSE tumor marker.

The obtained data on carcinogenic danger of copper-smelting production were also confirmed by the results of epidemiologic study on mortality caused by malignant neoplasms among workers employed at 
copper-smelting workshop. Intensive mortality indices for male workers employed at smelting and converting sections of copper-smelting workshop amounted to 153.14 as per all localizations (totally). This parameter amounted to only 127.25 per 100,000 among ordinary male population. Intensive mortality indices for workers employed at blister copper production which were higher than the same indices for population were detected for malignant neoplasms of respiratory organs and chest (86.78 and 47.72 correspondingly), including lung cancer (71.47 and 43.48 correspondingly). The greatest difference in levels of lung cancer mortality among workers employed at copper-smelting workshop and control population was detected in 50-59 age group (425.53 and 159.57 correspondingly) $(\mathrm{p}<0.05)$.

As we can see from Table 2, statistically significant multiplicity of observed mortality excess over expected mortality was detected among men employed at copper-smelting

Table 2

Ratio of observed mortality caused by malignant neoplasms to expected mortality among men employed at copper-smelting workshop (per 100,000 people)

\begin{tabular}{|c|c|c|c|c|}
\hline No. & Neoplasms localization & Observed & «Expected» & $\begin{array}{l}\text { Observed indices and } \\
\text { expected indices ratio }\end{array}$ \\
\hline 1 & Oral cavity and pharynx & - & $3,70 \pm 0,88$ & - \\
\hline \multirow{4}{*}{2} & Respiratory organs and chest, including: & $86,78 \pm 21,04$ & $40,70 \pm 2,94$ & $2,13^{*}$ \\
\hline & - trachea, bronchial tubes, lungs & $71,47 \pm 19,09$ & $37,40 \pm 2,82$ & 1,91 \\
\hline & - nasal cavity and larynx & $15,31 \pm 8,84$ & $2,52 \pm 0,73$ & 6,07 \\
\hline & - pleuroperitoneum and mediastinum & - & $0,78 \pm 0,41$ & - \\
\hline \multirow{7}{*}{3} & $\begin{array}{l}\text { Digestive organs and peritoneum organs, includ- } \\
\text { ing: }\end{array}$ & $25,52 \pm 11,41$ & $43,92 \pm 3,05$ & 0,58 \\
\hline & - esophagus & - & $2,04 \pm 0,66$ & - \\
\hline & - stomach & $15,31 \pm 8,84$ & $24,57 \pm 2,28$ & 0,62 \\
\hline & - bowels & $10,21 \pm 7,22$ & $6,49 \pm 1,17$ & 1,57 \\
\hline & - liver & - & $3,48 \pm 0,86$ & - \\
\hline & - pancreas & - & $5,88 \pm 1,12$ & - \\
\hline & - others & - & $1,46 \pm 0,55$ & - \\
\hline \multirow{3}{*}{4} & $\begin{array}{l}\text { Musculoskeletal system, connective tissue, skin, } \\
\text { including: }\end{array}$ & - & $4,32 \pm 0,96$ & - \\
\hline & - skin & - & $1,12 \pm 0,49$ & - \\
\hline & - bones and connective tissue & - & $3,20 \pm 0,82$ & - \\
\hline \multirow{3}{*}{5} & Urogenital organs, including: & $15,31 \pm 8,84$ & $8,90 \pm 1,37$ & 1,72 \\
\hline & - genital organs & $10,21 \pm 7,22$ & $2,19 \pm 0,68$ & 4,66 \\
\hline & - urinary organs & $5,10 \pm 5,11$ & $6,71 \pm 1,19$ & 0,76 \\
\hline 6 & Lymphatic organs and hematopoietic system & $5,11 \pm 5,11$ & $5,63 \pm 1,09$ & 0,91 \\
\hline 7 & Others & $20,42 \pm 10,21$ & $5,34 \pm 1,06$ & 3,82 \\
\hline 8 & All localizations taken together & $153,14 \pm 27,94$ & $112,51 \pm 4,88$ & 1,36 \\
\hline
\end{tabular}

Note: $*$ - discrepancies are statistically authentic $(\mathrm{p}<0.05)$.

workshop as per malignant neoplasms in respiratory organs and chest (2.13 times), including tumors in trachea, bronchial tubes and lungs (1.91 times), and nasal cavity and larynx (6.07 times). Besides, observed mortality exceeded expected mortality as per malignant neoplasms in urogenital organs (1.72 times), including genital organs (4.66 times), intestine tumors (1.57 times) and other localizations (3.82 times).

The obtained results will help to work out a system of CR managing which will include 
regulation and surveillance activities, basic carcinogens content doesn't exceed organization and management activities, MPC.

technical and technological activities, financial and economic activities, medical and prevention activities, rehabilitation, as well as information and educational activities. Providing hygienic safety and opportunity of technical achievement of goals set forth in risk managing are to become top criteria here; they should allow for economic efficiency of management decision-making. In future we should use technologies of insuring civil liability in relation to unforeseen damage to health and voluntary medical insurance of working population.

\section{Conclusions:}

1. In blister copper production, carcinogenic risk caused by exposure to arsenic, cadmium, lead, nickel, beryllium, and benzpyrene, lies within unacceptable range and is determined mostly by arsenic as other
2. The biggest carcinogenic risk values are detected for occupations with workplaces where dust emissions are the greatest, as well as for workers occupied with repair and auxiliary work.

3. Most workers who have occupations with unacceptable CR level also have increased levels of tumor markers.

4. Discrepancy between intensive mortality indices as per malignant neoplasms of different localization among workers employed at copper-smelting workshop and ordinary population proves there is an authentic correlation between neoplasms and impacts exerted by carcinogenic risks of production environment.

5. The obtained results will help to give grounds for a set of measures aimed at managing carcinogenic risks caused by shopfloor activity.

\section{References}

1. Adrianovskii V.I., Lipatov G.Ya. Ispol'zovanie otsenki professional'nogo kantserogennogo riska dlya rabochikh, zanyatykh $\mathrm{v}$ obogashchenii med'soderzhashchikh rud [Use of estimates of professional carcinogenic risk to workers employed in the enrichment of copper containing ores]. Sanitarnyi vrach, 2013, no. 10, pp. 46-49 (in Russian).

2. Adrianovskii V.I., Lipatov G.Ya., Lestev M.P. Gigienicheskaya kharakteristika vozdukha rabochei zony v sovremennom proizvodstve chernovoi medi [Hygienic characteristics of occupational air in the modern copper blister production]. Fundamental'nye issledovaniya, 2012, no. 7, pp. 16-20 (in Russian).

3. Lipatov G.Ya., Adrianovskii V.I. Vybrosy vrednykh veshchestv ot metallurgicheskikh korpusov medeplavil'nykh zavodov [Hygienic estimation of harmful substances emissions from metallurgical units of copper plants]. Sanitarnyi vrach, 2013, no. 8, pp. 41-43 (in Russian).

4. Lipatov G.Ya., Adrianovskii V.I., Gogoleva O.I. Khimicheskie faktory professional'nogo riska u rabochikh osnovnykh professii $\mathrm{v}$ metallurgii medi i nikelya [Chemical air pollution of the occupational environment as a factor for professional risk for workers of main occupations in the copper and nickel metallurgy]. Gigiena i sanitariya, 2015, no. 2, pp. 64-67 (in Russian).

5. Mel'tser A.V., Kiselev A.V. Gigienicheskoe obosnovanie kombinirovannykh modelei otsenki professional'nogo riska [Hygienic basis for combined models assessing occupational risks]. Meditsina truda i promyshlennaya ekologiya, 2009, no. 4, pp. 1-5 (in Russian).

6. Metodicheskie ukazaniya po retrospektivnomu izucheniyu smertnosti ot zlokachestvennykh novoobrazovanii v svyazi s vozmozhnym deistviem proizvodstvennykh faktorov [Methodical guidelines on retrospective study of mortality caused by malignant neoplasms in relation to influence possibly exerted by production factors]. Sverdlovsk, NII gigieny truda i profzabolevanii Publ., 1980, 23 p.

7. Gribova Yu.V., Bushueva T.V., Roslaya N.A., Silant'eva E.A., A.K. Labzova, Shmonina O.G., Otsenka prediktorov i markerov zlokachestvennykh novoobrazovanii legkikh u rabotnikov metallurgicheskogo predpriyatiya [Assessment of the predictors and markers of malignant tumors inthe lungs of 
metallurgical plant workers]. Vestnik ural'skoi meditsinskoi akademicheskoi nauki, 2015, no. 2, pp. 3236 (in Russian).

8. Rukovodstvo po ocenke riska dlja zdorov'ja naselenija pri vozdejstvii himicheskih veshhestv, zagrjaznjajushhih okruzhajushhuju sredu R 2.1.10.1920-04 [Guide to health risk assessment when exposed to chemicals polluting the environment R 2.1.10.1920-04 P]. Moscow: Federal'nyj centr Gossanjepidnadzora Minzdrava Rossii, 2004, 143 p. (in Russian).

9. Gurvich V.B., Kuz'min S.V., Vlasov I.A., Kuz'mina E.A., Lipatov G.Ya., Plotko E.G., Ruzakov V.O., Adrianovskii V.I., Kochneva N.I., Putilov I.L. Rezul'taty i metodologicheskie aspekty otsenki kantserogennoi opasnosti sub"ektov khozyaistvennoi deyatel'nosti na primere Sverdlovskoi oblasti [results and methodological aspects of the carcinogenic risk assessment for economic agents through the example of the Sverdlovsk region]. Zdorov'e naseleniya i sreda obitaniya, 2013, no. 4, pp. 6-8 (in Russian).

10. Adrianovskii V.I., Lipatov G.Ya., Zebzeeva N.V., Kuz'mina E.A. Rezul'taty izucheniya pylevogo faktora v pirometallurgii medi [Results of dust factor in copper pyrometallurgy]. Gigiena i sanitariya, 2016, no. 4, pp. 347350 (in Russian).

11.Kuz'min S.V., Privalova L.I., Kornilkov A.S., Kuz'mina E.A., Yarushin S.V., Plotko E.G. Rezul'taty mnogosredovoi otsenki riska dlya zdorov'ya naseleniya v promyshlenno razvitykh gorodakh Sverdlovskoi oblasti [The results of the multimedia health risk assessment in industrially developed cities of the Sverdlovsk region]. Ural'skii meditsinskii zhurnal, 2012, no. 10, pp. 12-14 (in Russian).

12. Gurvich V.B., Kuz'min S.V., Lipatov G.Ya., Adrianovskii V.I., Zebzeeva N.V., Beresneva O.Yu., Bushueva T.V., Ruzakov V.O. Rezul'taty otsenki kantserogennoi opasnosti s poetapnoi realizatsiei kompleksa sanitarno-gigienicheskikh i mediko-profilakticheskikh meropriyatii [The results of the evaluation of carcinogenic hazard with a phased implementation of a set of sanitary and medical preventive measuresin the context of copper smelting enterprises]. Vestnik ural'skoi meditsinskoi akademicheskoi nauki, 2015, no. 2, pp. 43-46 (in Russian).

13.Zebzeeva N.V., Lipatov G.Ya., Kuz'mina E.A., Russkikh K.Yu. Rezul'taty sravnitel'noi otsenki kantserogennykh riskov u rabotayushchikh pri raznykh sposobakh polucheniya chernovoi medi [The results of the comparative evaluation of carcinogenic risks in workers employed in different ways of producing blister copper]. Vestnik ural'skoi meditsinskoi akademicheskoi nauki, 2015, no. 2, pp. 50-52 (in Russian).

14.Serebryakov P.V. Ispol'zovanie otsenki kantserogennogo riska na gornorudnykh i metallurgicheskikh predpriyatiyakh Zapolyar'ya [Using the evaluation of carcinogenic risk in the mining and metallurgical enterprises of the Arctic]. Gigiena i sanitariya, 2012, no. 5, pp. 95-98 (in Russian).

15.Serebryakov P.V. Podkhody k optimizatsii ekspertizy professional'nykh zlokachestvennykh novoobrazovanii [Approaches to optimization of the occupational cancersexamination process]. Vestnik ural'skoi meditsinskoi akademicheskoi nauki, 2015, no. 2, pp. 80-83 (in Russian).

16.Strategiya razvitiya meditsinskoi nauki v rossiiskoi federatsii na period do 2025 goda [Development strategy for medical science in the Russian Federation for the period till 2025]. Available at: http: //legalacts.ru/doc/rasporjazhenie-pravitelstva-rf-ot-28122012-n-2580-r/ (11.08.2016) (in Russian).

17.Arsenic and arsenic compounds. IARC Monographs - 100C, 2012, pp. 41-93. Available at: http: //monographs.iarc.fr/ENG/Monographs/vol100C/mono100C-6.pdf (28.10.2016).

18.Chapter 27 - Biological monitoring. ILO Encyclopaedia of Occupational Health and Safety, Part IV - Tools and Approaches. Available at: http: //www.ilocis.org/documents/chpt27e.htm\#JD_Ch27_3 (28.10.2016).

19.Lauwerys R.R., Hoet P. Industrial Chemical Exposure: Guidelines for Biological Monitoring. CRC Press LLC, 2001, pp. 36-49.

20.Karnak D., Beder. S., Kayacan O. et. al. Neuron-specific enolase and Lung cancer. Am. J. Clin. Oncol, 2005, vol. 28, no. 6, pp. 586-590.

Adrianovskiy V.I., Lipatov G.Ya., Kuz'mina E.A., Zlygosteva N.V., Russkikh K.Yu., Sharipova N.P., Bushueva T.V., Ruzakov V.O. Assessing occupational carcinogenic risks for health of workers employed at blister copper production enterprise. Health Risk Analysis, 2017, no. 1, pp. 93-100. DOI: 10.21668/health.risk/2017.1.11.eng 
Received: 14.01.2017

Accepted: 02.03.2017

Published: 30.03 .2017 